\title{
Forestry in Saskatchewan
}

\author{
By ALEX DICKSON, Extension Forester, Prince Albert
}

EDITOR'S NOTE: This is the second in a series of articles on the conservation of our natura resources written especially for the BLUE JAY.

The face of Saskatchewan is slowly but inexorably changing. Time was when the province was wholly dependent upon its ability to produce first-rate milling wheat and, to produce it in abundance! Today, the chemical, oil, mining and forest industries are assuming a greater and greater economic importance. That is perhaps as it should be. After all, three-fifths of the land area of the province consists of forest, water and rock.

The forest land north of Prince Albert suppcrted one of the largest lumber mills in Western Canada at the turn of the century. At that time, river boats plied the Ncrth Saskatchewan River and logs were driven down many of the small tributaries. It is hard to imagine such happenings today: the forest boundary has receded so far that the nearest permanent sawmill is now located at Big River, some ninety miles northwest of the city, and so much debris has been deposited in the river that canoe travel is extremely difficult at certain times of the year. Saskatchewan's forests, like those of the rest of North America, suffered heavily at the end of the last century and the beginning of this. The trees that escaped the logger's axe ended their days on the funeral pyres of land clearing. To the men who wanted to till the soil, they represented only many months-even years-of hard, back-breaking labour. Thus the pioneer used any means he could to get rid of trees, sometimes needlessly destroying neighboring forest. Deterioration of the land, silted-up river beds and a lack of the larger type of timber have resulted.

Sad though the situation is, it is not hopeless. Since the end of World War II, steps have been taken to implement the provincial government's policy of "conserving, perpetuating and promoting the best ultimate use of Saskatchewan's forest wealth." The first task was that of taking stock. In 1947, the Inventory Division of the Forestry Branch, De- partment of Natural Resources, was set up on the recommendations of post-war Royal Commission on Forestry; it has since mapped and "as sessed" the entire 23,000,000 acr Commercial Forest Zone besides reconnoitering a further 43,000 square miles horth of the fifty-fifth parallel Thousands of sample plots, a fifth of an acre in size, were measured to supply basic data on volumes anc rates of growth, while 70,000 photos taken in the summer at altitudes o eight or nine thousand feet, providec the detail for the cover-type maps Although objects appear small from that height, the skilled reader photographs can determine the kin and height of trees and the densit of stands by examining the aeria pictures carefully.

The great interest taken today is the province's forest reserve is th result of this mammoth stocktakin which has revealed that there is a abundant supply of raw material fo a variety of industries using wooc Six billion cubic feet of pulpwood, a well as half as much again in th form of sawtimber, are ready to $b$ converted to paper and lumber. Nc cnly that, but this quantity of rar material from trees of all commercia species increases annually at the rat of $232,000,000$ cubic feet. Theoretic ally, by cutting only the annual in crement each year, the forest capit: is never depleted.

Only careful, long-range plannin however, can bring this about; an it is the function of the Managemer Division to make practicable work ing plans. While it cannot truthfull be said that "sustained yield" is be ing achieved at the present tim cautious exploitation is at least $r \epsilon$ ducing the number of over-age tree and giving a more favorable distribu tion of all actively growing ages.

The Silviculture and Extensic Division performs many function: the forests are aided in the regener: tion of themselves by both natur and artificial means; land is assigne to its proper use, either for agricu ture or forestry; private woodlar 


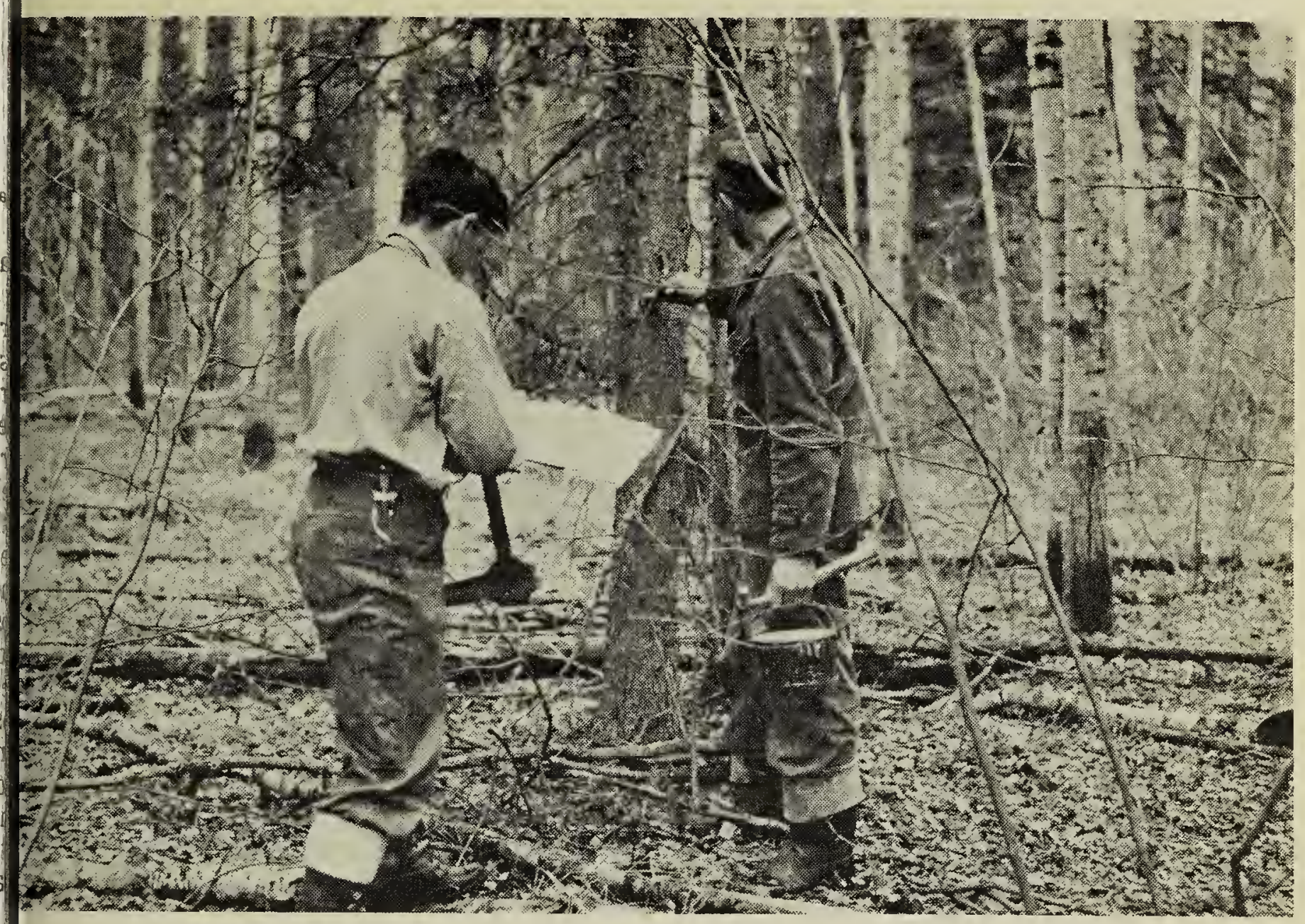

Sask. Gov't Photo by G. Savage ventory forester and assistant tally and mark trees in a sample plot during a stock-taking rvey.

wners are given guidance in the anagement of their property; and ren forest pastures are carefully ssessed on the basis of their stockrrying capacities.

The infant of the Forestry Branch the Research Division. It is investiating the various problems connect$d$ with growth, yield, decay and reeneration, as well as testing the pplicability of scientific findings to askatchewan conditions.

The harvesting and marketing of rest products each year are in the large of the Saskatchewan Timber card. This Crown Corporation assts with the building of access roads and insists on a high degree of utilation by the various sub-contracrs. Thus a close check on the for'ts' annual yield is kept, and the perations are subjected to a degree "quality control."

Saskatchewan forests are remarkbly free from injurious insects and iseases. The major insect pests are ie larch sawfly and the forest tent aterpillar. Both are leaf-eaters. The rmer attacks tamarack, and was sponsible for the almost total eclipse of that species in the 1920's; whereas the latter has several times in the last thirty years rendered vast stands of poplar leafless in the middle of summer. These defoliations, however, do more to reduce increment than to kill. Outbreaks of jack pine and spruce budworm have been recorded, but the damage done has given little cause for alarm.

Only jack pine suffers from the "attentions" of a parasitic plant known as dwarf mistletoe. This plant deforms the trees, rendering them unsightly and worthless for timber and poles. Heart-rot fungi are prevalent to some degree in all species, and are a source of waste, both in time and material.

Forests are protected by a Fire Control Branch, which proudly boasts the only parachutist, fire-suppression unit in the British Commonwealth - the Saskatchewan Smokejumpers. Modelled on the world-famous group of American fire-fighters in Montana, the smokejumpers were organized in 1947 to stop the spread of fires while they were still small. Today, they may still be regarded as the shock-troops 


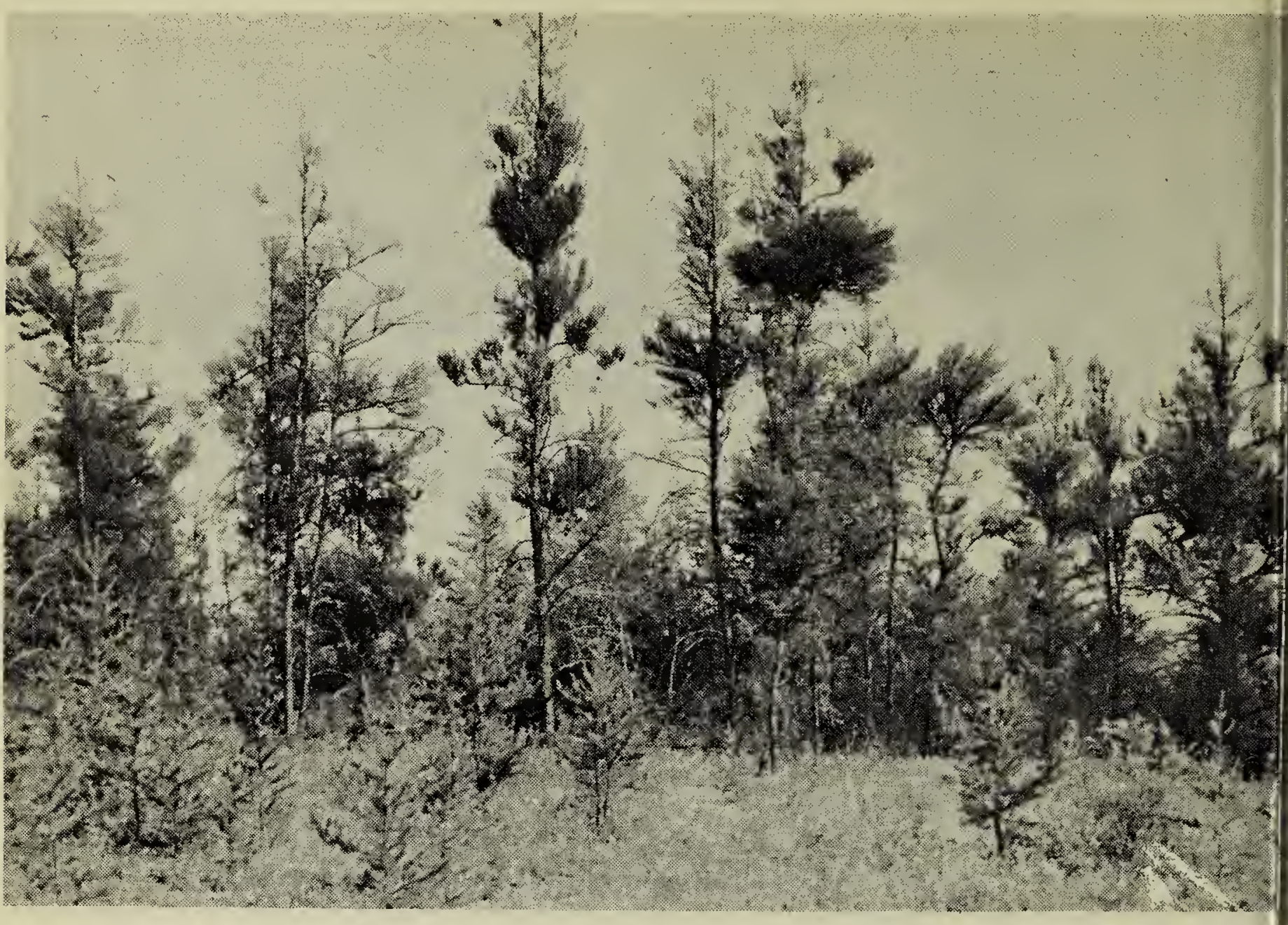

Sask. Qov't Photo by G. Savag

Dwarf. Mistletoe, an insidious parasite of jack pine, manifests itself here in witches' broor (unsightly clumps of branches). The only cure is removal of the infected trees.

of the fires-fighting force, "holding the line" until reinforcements arrive.

As soon as a "smoke" is spotted by any of the 80 fire towers, strategically located to provide almost complete coverage of the Commercial Forest Zone, or by aircraft of the special fleet which patrols during periods of high hazard, the men are flown from their base at Lac la Ronge and dropped from an altitude of approximately 2,000 feet. Owing to their special training and protective clothing, the parachutists can land among trees without injuring themselves. In fact, the jump-master says he is worried more about the equipment than the men. When the fire is out or when reinforcements arrive, the smokejumpers walk out to the nearest lake and radio for their plane to take them back to base.

Of course, prevention is superior to cure. A vigorous propaganda campaign reaches the province's farflung population through motion pictures, press and radio. Each year a Forest Conservation Week is set aside to encourage every resident of the forest area to value the forest and what it contains. Speakers of national renown who have come to addres meetings in various communities ? this time include C.B.C.'s John Fishe and Mrs. Kay Russenholt, the Cana dian Forestry Association's J. L. Va Camp, and Weekend Magazine's edil or and columnist, Gregory Clar, This year, the guest was Mr. Roder ick Haig-Brown, noted conservatic writer of Vancouver Island.

In Saskatchewan only nine speci of trees are considered of commerci value. They are: white ispruce (Pice glauca), black spruce (P. mariana balsam fir (Abies balsamea), jad pine (Pinus banksiana), lodgepo pine ( $P$. contorta var. latifolio) ar tamarak (Larix laricina) from t] conifers; and white Roplar or asp (Populus tremuloides), black popl $(P$. balsamifera) and white bir (Betula papyrifera) from the broa leaved trees. The distribution these trees gives rise to the follor ing zones:

(1) The Prairie Belt, where tre are noticeably lacking except in 1 calities of high elevation such as $t$ Cypress Hills.

(2) The Aspen Grove Belt, w aspen or white poplar predominatis 
(3) The Mixedwood Belt, where species are present.

(4) The Northern Coniferous ForBelt, where the broad-leaved es are entirely lacking or very uch in the minority.

(5) The Arctic Tundra Belt, where permanently frozen subsoil has used stunted growth, making this gion veritably "the land of little cks."

Forest management so far has ainly been put into effect in the ixedwood Belt, because of its easy cessibility and the availability of e different species. Later, other gions will come under more intenve management.

The government of Saskatchewan keenly aware of the province's eat forest resources, and is eager to tract industries which will use em. Today, a small fibreboard plant nearing completion, a blockboard ant is committed to begin operans next year and an agreement has en signed with a pulp firm which tends to establish a $\$ 60,000,000$ ant near Prince Albert within the xt two years. Two more pulp mpanies are negotiating for limits, as well as a firm interested in the production of chipboard.

These industries are not to be established at the expense of our forest resources. Management plans based on sound forestry principles have to be prepared by the companies and subrnitted to the government for approval either before operaticns begin or a year ar two after. Further assurance of proper management and accurate statement of production returns is the financial deposit required of the companies, and their compulsory employment of government licensed scalers.

No longer, it is hoped, will Saskatchewan be rated only as a "wheat province"; trees also are a valuable crop.

\section{BINOCULARS FOR SALE}

$10 \times 50$ binoculars with case. Coated lens. Field $5^{\circ}$. Army and Navy Special. Individual eyepiece focussing. \$30. Write F. W. Lahrman, Sask. Museum of Natural History, Regina.

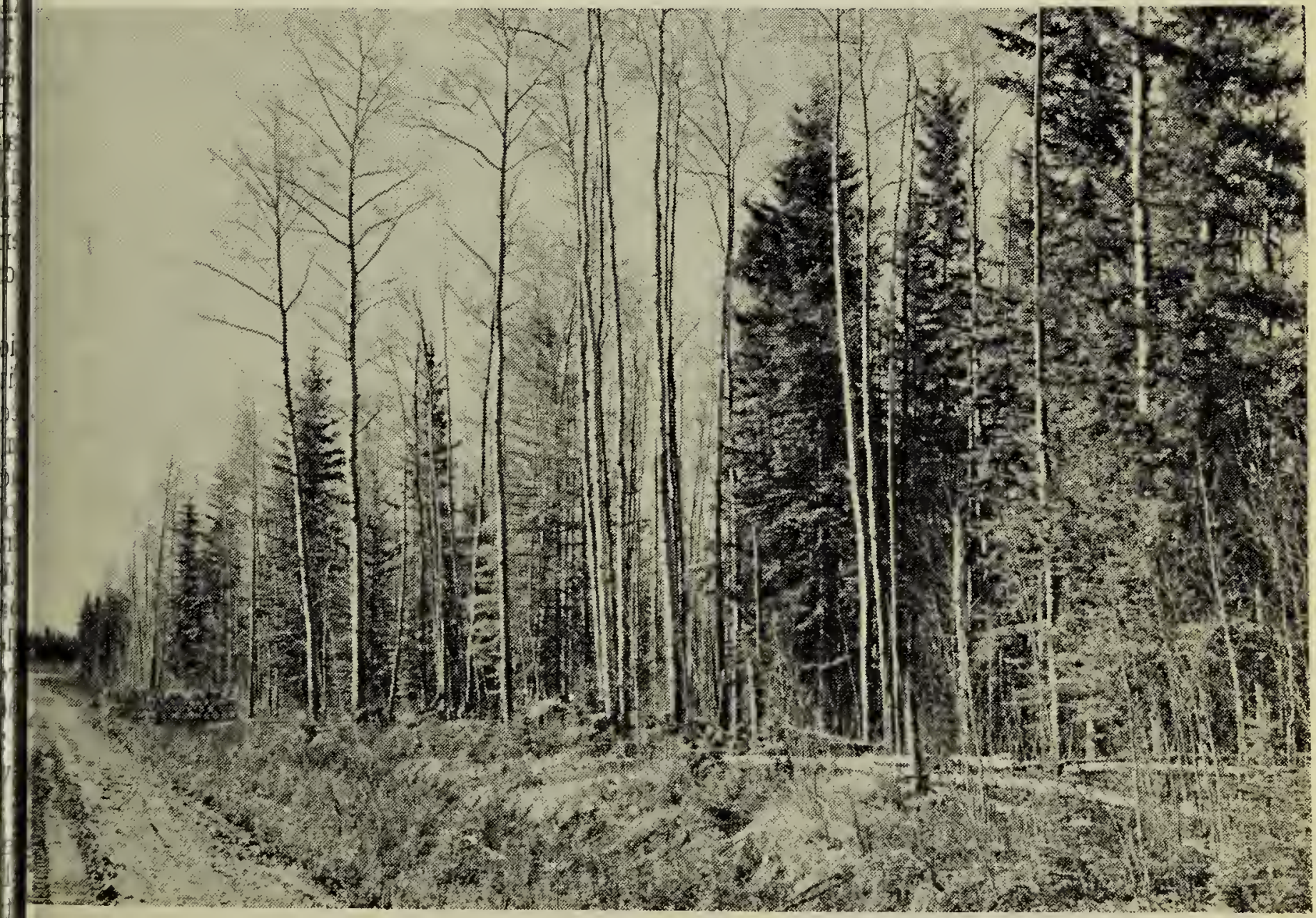

Sask. Gov't Photo by G. Savage hite spruce occurs naturally under the beneficial shade of aspen. Here, in a typical mixedood stand, the spruce is rapidly overtaking the poplar and will eventually gain the ascendicy. 